\title{
Interaction of Ganglioside GM1 with the B Subunit of Cholera Toxin Modulates Growth and Differentiation of Neuroblastoma N18 Cells
}

\author{
Daniel Masco, ${ }^{1}$ Michele Van de Walle, ${ }^{2}$ and Sarah Spiegel ${ }^{1}$ \\ ${ }^{1}$ Department of Biochemistry and Molecular Biology, Georgetown University Medical Center, Washington, DC 20007, and \\ 2Biotechnology Unit, LCDB, NIDDK, NIH, Bethesda, Maryland 20892
}

The present study uses the B subunit of cholera toxin, a protein that binds specifically to ganglioside GM1, to examine the role of endogenous GM1 in the process of growth and differentiation of mouse neuroblastoma N18 cells. Binding of the B subunit to neuroblastoma N18 cells inhibited DNA synthesis with concomitant induction of differentiation. The B subunit induced pronounced morphological changes: an increase in neurite outgrowth with branched neurites and spinelike processes. The distinct morphological alterations and neuritogenesis in response to the $B$ subunit were also revealed by immunofluorescence with fluorescein-labeled $B$ subunit. The mechanism of the $B$ subunit-induced differentiation is different than that of spontaneous differentiation. Thrombin, a serine protease present in normal serum, inhibits neurite outgrowth induced by the removal of serum from the medium. In contrast, thrombin did not cause retraction of the neurites induced by the B subunit. Thus, thrombin or a thrombin-like protease is not involved in the process of neurite outgrowth mediated through endogenous GM1. The biological effects of the $B$ subunit are due to the binding of the $B$ subunit to ganglioside GM1 and not due to changes in cAMP levels resulting from contaminating A subunit. We used highly purified cloned $B$ subunit that cannot contain any $A$ subunit because it was isolated from a Vibrio cholerae mutant that only expresses the B subunit. Neither the cloned nor commercial preparations of the B subunit induced increases of CAMP in these cells. There was a good correlation between the amount of $B$ subunit bound to the cells and the biological effect. Finally, treatment with neuraminidase, which caused a fourfold increase in the level of membrane GM1 as determined by iodinated cholera toxin binding, enhanced the biological effect of the $B$ subunit. However, neuraminidase treatment alone did not have significant effects, either on DNA synthesis or on morphology of the cells, indicating that elevations in the level of GM1 per se are not sufficient by themselves to cause significant changes in cell growth or differentiation. It seems most likely that the aggregation

\footnotetext{
Received Oct. 18, 1990; revised Feb. 27, 1991; accepted Mar. 12, 1991.

This work was supported by NIH Research Grants 1 R 29 GM 39718 and 1 R 01 GM 43880. D.M. was supported in part by Alzheimer's Disease and Related Disorders Association, Inc., Grant PRG 89087 . We thank Dr. J. Shiloach for critically reviewing the manuscript and for advice during the course of this work and Dr. M. Nirenberg for providing neuroblastoma N18 cells.

Correspondence should be addressed to Dr. Sarah Spiegel, Department of Biochemistry and Molecular Biology, Georgetown University Medical Center, 357 Basic Science Building, 3900 Reservoir Road Northwest, Washington, DC 20007. Copyright (C) 1991 Society for Neuroscience $0270-6474 / 91 / 112443-10 \$ 03.00 / 0$
}

of endogenous GM1 on the cell surface by the B subunit is responsible for these effects on mouse neuroblastoma N18 cells.

Gangliosides, sialic acid-containing glycosphingolipids, are ubiquitous components of the plasma membrane of vertebrate cells (Sweeley and Siddiqui, 1977) and are particularly enriched in neural cells (Ledeen, 1985). The abundance and the structural complexity of gangliosides in nerve cells, combined with the observation that gangliosides vary considerably in composition and concentration during neuronal development and differentiation (Hakomori, 1981; Yates, 1986), suggest that gangliosides have important functional roles in neuronal development in vivo. Further support for this contention is that neuronal cells respond uniquely to exogenous gangliosides with profound morphological changes characteristic of differentiation (Ledeen, 1985). The observations that exogenously administered gangliosides have neuritogenic and neuronotrophic properties capable of influencing neuronal differentiation in vitro and neuronal repair in vivo have provided possible links to this aspect of ganglioside function (Ledeen, 1985).

Many neuronal cell types respond to exogenous gangliosides with concomitant sprouting and extension of neurites, including neuroblastoma cell lines Neuro2A (Dimpfel et al., 1981; Roisen et al., 1981; Leon et al., 1982; Byrne et al., 1983; Spoerri, 1983), SB21B1 (Rybak et al., 1983), GOTO, and NB-1 (Tsuji et al., 1983); neuronal cell lines B103 and 104 (Morgan and Seifert, 1979); pheochromocytoma PC12 cells (Ferrari et al., 1983; Katoh-Semba et al., 1984); and primary cultures of dorsal root ganglia (Roisen et al., 1981), spinal root ganglia (Hauw et al., 1981), and cerebrum (Dreyfus et al., 1984). Exogenous gangliosides have important effects on the regulation of neural differentiation, not only in tissue culture systems, but there is no doubt that they facilitate regeneration of damaged PNS and CNS neurons (reviewed in Ledeen, 1985). The monosialoganglioside GM1 [Svennerholm's (1963) system of ganglioside nomenclature], in particular, has been shown to cause differentiation of neuronal cultures, to enhance sprouting of regenerative peripheral nerves, and to accelerate repair of CNS damage (Facci et al., 1984; Ledeen, 1985). However, though the effects of exogenous GM1 are very well documented, the relationship between these observations and the function of endogenous gangliosides in the process of cellular differentiation remains unclear, and no connection has yet been established between the effects of exogenous gangliosides and the role of endogenous gangliosides.

There are conflicting data on the role of endogenous ganglioside GM1 in neuritogenesis (Schwartz and Spirman, 1982; 
Mahadik et al., 1986; Doherty and Walsh, 1987; Spoerri et al., 1988). Doherty and Walsh (1987) found that antibodies to GM1 had no effect on NGF-induced outgrowth in chicken dorsal root ganglia. In contrast, others have reported that their anti-GM1 antibodies blocked NGF-induced sprouting of the same cells (Schwartz and Spirman, 1982; Mahadik et al., 1986) and also inhibited neurite outgrowth from regenerating retinal explants of the goldfish (Spirman et al., 1982). Recently, it was found that monoclonal antibodies to GM1 inhibit conditioned mediamcdiated ncuritogenesis of sensory ganglia (Spoerri et al., 1988). Furthermore, it has been recently reported that there is a correlation between the level of endogenous GM1 and the ability of the cell line to undergo neuritogenesis (Cannella et al., 1988).

To gain more insight into the putative role of endogenous ganglioside GM1, we have used the binding or B subunit of cholera toxin (CT). The major advantage of this approach lies in the specificity of the B subunit and the very high affinity for ganglioside GMl (Fishman, 1982). Previously, we found that the B subunit stimulated the growth of rat thymocytes (Spiegel et al., 1985b) and quiescent cultures of murine 3T3 fibroblasts (Spiegel and Panagiotopoulos, 1988). However, in contrast to its effect on resting cells, the B subunit inhibited the growth of ras-transformed 3T3 fibroblasts (Ha-, $\mathrm{Ki}-$, and N-ras; Spiegel and Fishman, 1987) and rat glioma C6 cells with elevated levels of GMl (Spiegel, 1988). Recently, the studies with the C6 cells were confirmed and further extended by the demonstration that neuraminidase (NA) treatment, which increases the amount of cell-surface ganglioside GM1, also induced susceptibility to the inhibitory effect of the B subunit (Skaper et al., 1988). Furthermore, the B subunit not only inhibited the growth of astroglial cells but also induced marked differentiation to a stellate morphology (Facci et al., 1988; Dekker et al., 1990).

The purpose of this study was to extend this approach to the involvement of membrane ganglioside GM1 in the process of differentiation and growth of neuronal cells. Mouse neuroblastoma N18 cells seem to be especially suitable for this purpose, because they have a ganglioside composition similar to that of primary neuronal cells (Duffard et al., 1977), have large amounts of surface ganglioside GM1 when analyzed by chemical assays or surface labeling techniques (Miller-Podraza and Fishman, 1982; Miller-Podraza et al., 1982), and can easily be induced to differentiatc by various stimuli, such as dibutyryl c $\Lambda \mathrm{MP}$, tumor promoters, and the removal of serum (Liu et al., 1980). The results presented here indicate that binding of the $B$ subunit of CT to endogenous plasma membrane ganglioside GM1 can influence the growth and differentiation of a neuronal cell line.

\section{Materials and Methods}

Materials. CT and its B or binding subunit were obtained from Schwarz/ Mann Biotech (Cleveland, $\mathrm{OH}$ ). The B subunit appeared to be holotoxin free by SDS-PAGE because there was no detectable $M, 22,000$ band of the Al subunit by silver staining. Fluorescein-conjugated $B$ subunit was from List Biological Labs (Campbell, CA). ${ }^{3} \mathrm{H}$-thymidine $(55 \mathrm{Ci} / \mathrm{mmol})$ was purchased from ICN (Irvine, CA). Thrombin, insulin, transferrin, and selenium were from Collaborative Research (Lexington, MA). Dulbecco's modified Eagle's medium (DMEM) was from Advanced Biotechnologies (Silver Spring, MD). 1-Methyl-3-isobutylxanthine (IBMX) was from Sigma Chemical Co. (St. Louis, MO).

Production of highly purified cloned B subunit. The B subunit was produced as recently described (Van de Walle ct al., 1990). Bricfly, a defined medium was used to grow a mutant of Vibrio cholerae (0395$\mathrm{NI}$ ), which carries a deletion in the cbcA gene and thus produces only the B subunit of CT (Taylor et al., 1987). Culture supernatants were ultrafiltered and purified on a phosphocellulose column.

Cell culture. The murine neuroblastoma cell line N18 was kindly provided by Dr. M. Nirenberg, NHLBI, NIH. Stock cultures of cells were maintained in DMEM supplemented with $5 \%(\mathrm{v} / \mathrm{v})$ fetal bovine serum, respectively, in a humidified atmosphere of $5 \% \mathrm{CO}_{2}, 95 \%$ air at $37^{\circ} \mathrm{C}$. Upon reaching stationary phase of growth, the cells were subcultured by flushing the cells off their growing substratum with a stream of medium and diluting the cell suspension 1:4 with fresh medium.

Measurement of DNA synthesis. Cells were seeded at a density of 2.5 $\times 10^{4}$ cells per well in multicluster plastic tissue culture dishes $(24 \times$ $16 \mathrm{~mm}$ wells; Costar, Cambridge, MA) in DMEM containing different concentrations of fetal calf serum. In some experiments, the cells were grown in chemically defined serum-free medium (medium I), which consists of DMEM supplemented with insulin $(5 \mu \mathrm{g} / \mathrm{ml})$, transferrin $(5$ $\mu \mathrm{g} / \mathrm{ml})$, and selenium $(5 \mathrm{ng} / \mathrm{ml})$. At a density of about $6-8 \times 10^{4}$ cells per well, the cells were washed with DMEM to remove residual serum and treated with different concentrations of the B subunit. After $20 \mathrm{hr}$, the cells were pulsed with 0.5 or $1 \mu \mathrm{Ci}$ of ${ }^{3} \mathrm{H}$-thymidine for $4 \mathrm{hr}$. The incorporation of radioactivity into trichloroacetic acid-insoluble material was measured as described by Spiegel and Fishman (1987). Values are the mean of triplicate determinations, and standard errors were routinely less than $10 \%$ of the mean.

Morphological evaluation of neurite outgrowth. Cells were treated with the B subunit exactly as described above. After $24 \mathrm{hr}$, the cells were rinsed with PBS, fixed for $1 \mathrm{hr}$ in PBS containing 4\% formaldehyde and $5 \%$ sucrose, then rinsed three times with PBS, and photographs were taken. The numbers of cells bearing neurites were counted in several randomly chosen fields containing approximately 200 cells at a microscopic magnification of $200 \times$. Neurites were identified by the presence of growth cones. Cytoplasmic extensions were scored as neurites if their length exceeded twice the diameter $(20 \mu \mathrm{m})$ of the neuroblastoma soma (Matta et al., 1986)

Assay of CAMP. Accumulation of cAMP in the cells was determined essentially as we described previously (Spiegel et al., 1985b; Spiegel, 1988). Briefly, cells were incubated for $5 \mathrm{~min}$ at $37^{\circ} \mathrm{C}$ in $1 \mathrm{ml}$ of medium buffered with $25 \mathrm{~mm}$ HEPES and supplemented with $0.5 \mathrm{mM}$ IBMX, a phosphodiesterase inhibitor, and $0.01 \%$ bovine serum albumin. After incubations with various reagents, cAMP was extracted from the cells with $0.1 \mathrm{M} \mathrm{HCl}$ and measured by radioimmunoassay. The precipitated proteins remaining in the dish were dissolved in $0.2 \mathrm{~m} \mathrm{NaOH}$ and measured (Lowry et al., 1951).

Measurement of specific binding of iodinated $C T$. Binding of iodinated CT to cells in situ was measured as described (Spiegel et al., 1985b; Spiegel, 1988). Briefly, cells subcultured in 16-mm-diameter wells were incubated with iodinated CT $(0.1-100 \mathrm{nM})$ in $0.5 \mathrm{ml}$ of serum-free medium buffered with $25 \mathrm{~mm}$ HEPES and supplemented with $0.1 \%$ bovine serum albumin. After $1 \mathrm{hr}$ at $37^{\circ} \mathrm{C}$, the medium was removed, and bound toxin was determined. Nonspecific binding was determined by the addition of $0.2 \mu \mathrm{M}$ unlabeled CT to the assay. All values were corrected for nonspecific binding and are the means of quadruplicate determinations.

Treatment of cells with thrombin. Cells were washed with medium to remove residual scrum and incubated with different concentrations of highly purified thrombin at $37^{\circ} \mathrm{C}$ in serum-free medium for various times (Gurwitz and Cunningham, 1988). The cells were then treated with the $B$ subunit as described above.

Distribution of the B subunit of CT by fluorescence microscopy. Cells were subcultured on glass coverslips in medium I. At various times after treatment with fluorescein-conjugated B subunit $(4 \mu \mathrm{g} / \mathrm{ml})$, the cells were rinsed with PBS, fixed for $1 \mathrm{hr}$ in PBS containing 4\% formaldehyde and $5 \%$ sucrose, and then rinsed three times with PBS and examined by fluorescence microscopy with a Zeiss microscope modified for epifluorescence, performed exactly as described previously (Spiegel et al., 1985a). Routine negative controls included treating the cells with excess amounts of unlabeled B subunit or with a large excess of ganglioside GM1.

\section{Results}

The $B$ subunit inhibits DNA synthesis and growth of neuroblastoma $N 18$ cells

Previously, we found that the interaction of the B subunit with endogenous ganglioside GM1 leads to stimulation or inhibition of proliferation, depending on the particular cell type and even 

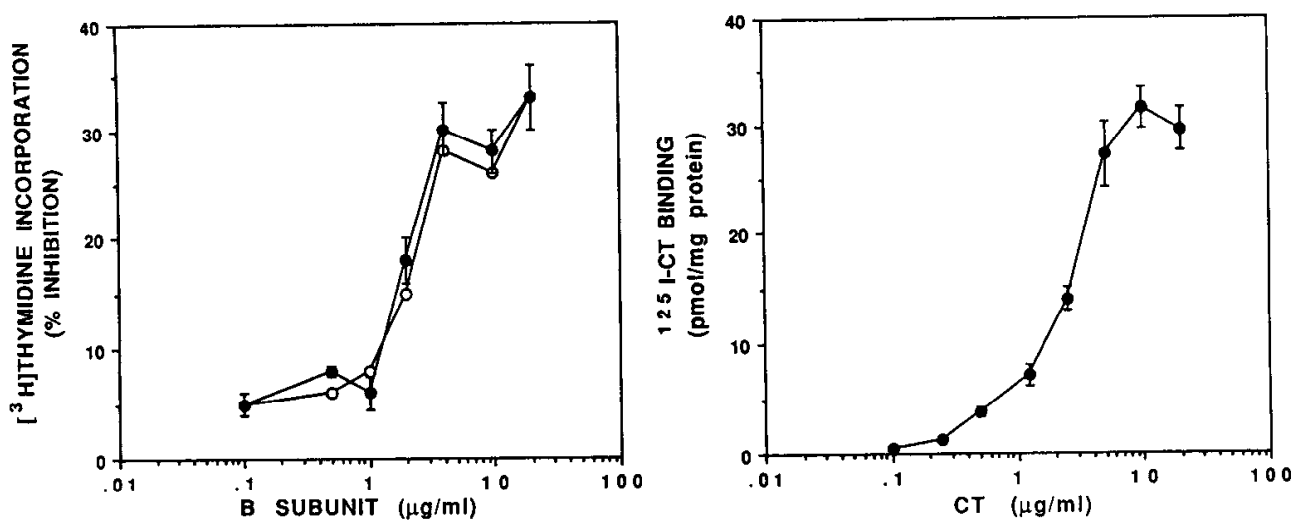

Figure 1. Dose-dependent effect of the $B$ subunit of CT on DNA synthesis correlates with iodinated $C T$ binding to $\mathrm{N} 18$ cells. Cells grown in DMEM medium suplemented with $1 \%$ FCS were exposed to various concentrations of $B$ subunit obtained commercially $(O)$ or to cloned B subunit $(\Theta)$ and assayed for ${ }^{3} \mathrm{H}$-thymidine incorporation as described in Materials and Methods. The results are expressed as the percent inhibition of DNA synthesis compared to cells not exposed to the B subunit. The amount of ${ }^{3} \mathrm{H}$-thymidine incorporated into control cells was $70 \pm 5 \times 10^{3} \mathrm{cpm}$ per well. Specific iodinated CT binding was determined on duplicate cultures as described in Materials and Methods. on their growth stage (Spiegel and Fishman, 1987; Spiegel, 1988; Buckley et al., 1990). The effect of the B subunit on the proliferation of mouse neuroblastoma cell line N18 is shown in Table 1. Experiments with $\mathrm{N} 18$ cells grown in different serum concentrations revealed that the inhibition of DNA synthesis by the $B$ subunit increased as the amount of serum was decreased (Table 1). A maximum inhibition of $25 \%, 24 \%, 15 \%$, and $17 \%$ was found with cells that were cultured in medium containing $0 \%, 1 \%, 2.5 \%$, and $5 \%$ fetal calf serum (FCS), respectively. Although these experiments were done on cells grown in culture for $3 \mathrm{~d}$ prior to the addition of the B subunit, similar results were found when the cells were cultured for $1 \mathrm{~d}$ (data not shown). $\mathrm{N} 18$ cells proliferated maximally in chemically defined medium containing insulin, transferrin, and selenium (Table 1). In these conditions, the growth of cells was even greater than observed in the presence of serum. A maximum inhibition of DNA synthesis induced by the B subunit was found with $\mathrm{N} 18$ cells grown in this chemically defined medium of $40 \%$ and $42 \%$ after $l$ and $3 \mathrm{~d}$ of culture, respectively. Thus, the time period in culture prior to the addition of the B subunit is not an important factor. The antiproliferative activity of the B subunit was not associated with any cytotoxic effects, because the number of viable cells, determined by trypan blue exclusion, was always greater than $95 \%$. Also, there was no apparent loss of cells during this period, and the $B$ subunit had no effect on cell adhesion because identical results were obtained using a cell harvester (data not shown). Uptake studies demonstrated that the effect of the B subunit was not due to a decrease in ${ }^{3} \mathrm{H}$-thymidine transport into the cells (data not shown). The B subunit caused a dose-dependent inhibition of DNA synthesis (Fig. 1). A significant effect was observed at a concentration of $1 \mu \mathrm{g} / \mathrm{ml}$, and maximum response to the B subunit was observed at a concentration of $2-4 \mu \mathrm{g} / \mathrm{ml}$. While these experiments were carried out using B subunit purified from holotoxin (Schwarz-Mann), an identical dose response was found using a highly purified preparation of the $\mathrm{B}$ subunit produced in a mutant of $V$. cholerae expressing only the B subunit (Fig. 1). The dose dependency for the growth inhibition effect by both preparations of the $B$ subunit correlated closely with the dose dependence of iodinated CT binding (Fig. 1).

\section{Lack of an effect on the level of intracellular cAMP by the B subunit}

Numerous studies have shown that an elevation in intracellular cAMP concentration is an important signal for neuritogenesis in neuronal cells (Richter-Landsberg and Jastorff, 1986). An increase in the intracellular level of CAMP can inhibit the growth of mouse neuroblastoma N18 cclls (Prasad and Hsie, 1971). To eliminate the possibility that the inhibition of DNA synthesis by the $\mathrm{B}$ subunit was due to a small contamination with the $\mathrm{A}$ subunit, which is known to activate adenylate cyclase by ADP. ribosylation of the stimulatory G-protein (Gilman, 1984), we used the cloned B subunit produced in $V$. cholerae mutants that did not express the A subunit. However, it seems most likely that the commercial preparation of the B subunit used in this study was also devoid of significant contamination with the A

Table 1. Effects of the B subunit on ${ }^{3} \mathrm{H}$-thymidine incorporation in mouse neuroblastoma $\mathrm{N18}$ cells

\begin{tabular}{|c|c|c|c|c|}
\hline \multirow{2}{*}{$\begin{array}{l}\text { Culture } \\
\text { condition } \\
\end{array}$} & \multicolumn{2}{|c|}{$\begin{array}{l}{ }^{3} \mathrm{H} \text {-thymidine incorporation } \\
\left(\mathrm{cpm} \times 10^{-3} \text { per well }\right)\end{array}$} & \multirow[b]{2}{*}{$\%$ Inhibition } & \multirow[b]{2}{*}{$p$} \\
\hline & Control & B subunit & & \\
\hline Medium I & $86.8 \pm 5$ & $50.1 \pm 3.8$ & 42 & $<0.01$ \\
\hline $0 \% \quad$ FCS & $15.8 \pm 0.7$ & $11.8 \pm 0.5$ & 25 & $<0.01$ \\
\hline $1 \% \quad$ FCS & $73.1 \pm 1.1$ & $56.0 \pm 0.2$ & 24 & $<0.01$ \\
\hline $2.5 \%$ FCS & $71.4 \pm 3.5$ & $60.7 \pm 3.9$ & 15 & $<0.05$ \\
\hline $5 \% \quad$ FCS & $53.0 \pm 6.3$ & $44.1 \pm 5.0$ & 17 & $<0.05$ \\
\hline
\end{tabular}

Cells were grown for $3 \mathrm{~d}$ in the indicated medium and then incubated in the absence (control) or presence of the $\mathrm{B}$ subunit $(4 \mu \mathrm{g} / \mathrm{ml})$ for $20 \mathrm{hr}$. ${ }^{3} \mathrm{H}$-thymidine incorporation was measured as described in Materials and Methods. Each value is the mean \pm SD of triplicate determinations from a representative experiment. Statistical analyses of the data were done by Student's $t$ test. Similar results were obtained in at least six additional experiments. 


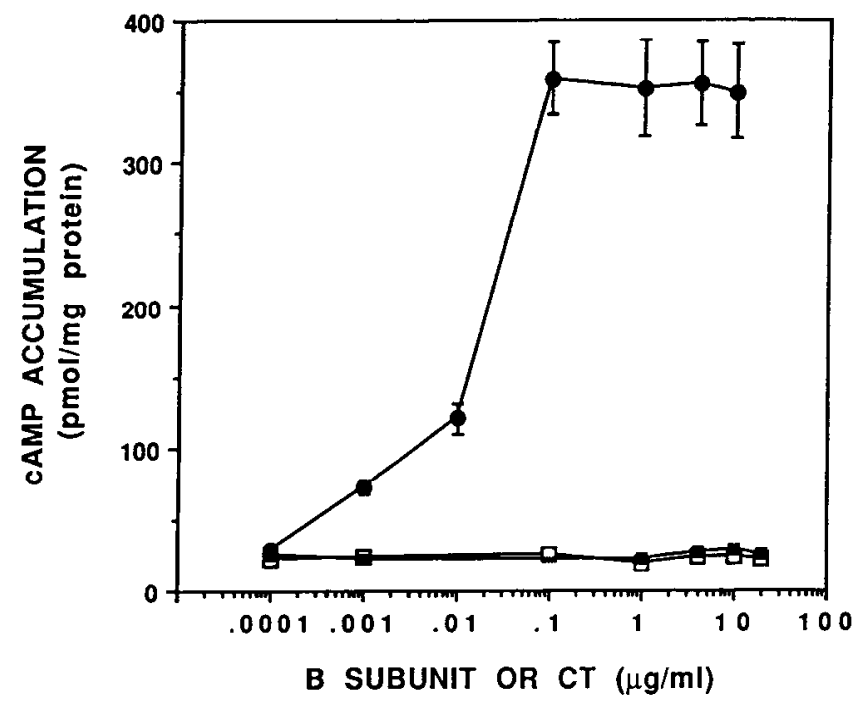

Figure 2. Effect of CT and two B subunit preparations on cAMP production. Cultures of N 18 cells were washed with DMEM and incubated at $37^{\circ} \mathrm{C}$ with the indicated concentrations of CT (O), the commercial B subunit (a), or the B subunit clone (a) in DMEM/HEPES containing IBMX $(0.5 \mathrm{mM})$. Cellular content of cAMP was assayed after $2 \mathrm{hr}$ by radioimmunoassay as described in Materials and Methods. The values are the means $(n=3)$. The SDs were less than $10 \%$.

subunit, based on the inability of either of the preparations of $B$ subunit to cause any significant accumulation of cAMP in N18 neuroblastoma cells. In agreement with several previous studies, (Fishman, 1980, 1982), the intact CT caused a dosedependent increase in cAMP production in thesc cclls (Fig. 2), and cAMP reached maximum levels after $2 \mathrm{hr}$ of exposure (data not shown). In contrast, cAMP levels in cells treated with the $B$ subunit preparations over a wide concentration range were not significantly different from untreated cells. It should be noted that intact CT, even at concentrations of $0.1-10 \mu \mathrm{g} / \mathrm{ml}$, which caused up to a 16-fold increase in cAMP production (Fig. 2), was less effective than the B subunit in inhibiling DNA synthesis. In cells grown in $1 \%$ FCS for $1 \mathrm{~d}$, a maximum inhibition of DNA synthesis of $34 \%$ or $26 \%$ was induced by $2 \mu \mathrm{g} / \mathrm{ml}$ of either the B subunit or the holotoxin, respectively.

\section{Inhibition of DNA synthesis by the B subunit in N18 cells after} treatment with $N A$

Because NA treatment is known to increase levels of ganglioside GM1 in N18 cells (Miller-Podraza and Fishman, 1982; MillerPodraza ct al., 1982), it was of interest to study the effect of the
B subunit on these cells in which the endogenous levels of GM1 are elevated. In agreement with previous studies (Miller-Podraza et al., 1982), when intact cells were treated with NA, there were profound changes in ganglioside composition (Table 2). The amount of GM3 and GDla was reduced by $73 \%$ and $80 \%$, respectively, and GM1 increased 3.5 -fold. There was also a corresponding increase in iodinated CT binding to the NAtreated cells (data not shown). The maximum effect appeared to occur after $2 \mathrm{hr}$ of exposure to $\mathrm{NA}(0.01 \mathrm{U} / \mathrm{ml})$. The increase in the level of GM1 corresponded to the increased inhibition of DNA synthesis in response to the B subunit (Table 3). Exactly the same results were obtained using the cloned $B$ subunit. Treatment with NA alone for $24 \mathrm{hr}$ had no effect on the proliferation in chemically defined medium or in $1 \%$ FCS (Table 3). However, when the cells were grown in higher concentrations of FCS, there was a small inhibitory effect of NA treatment.

\section{$B$ subunit induces morphological differentiation in mouse neuroblastoma $\mathrm{N} 18$}

Neuroblastoma N18 cells cultured in the presence of 5\% FCS have a round and aggregated morphology (Fig. $3 A$ ). Addition of B subunit $(4 \mu \mathrm{g} / \mathrm{ml})$ to these cells, growing in a compact fashion as bundles of dividing cells, causes morphological differentiation (Fig. $3 B$ ). The aggregate growth pattern of the N18 cells growing in $5 \%$ FCS complicated the evaluation of a more frequently used parameter for neurite outgrowth, the percentage of cells bearing neurites, because of uncertainty about the cellular origin of the processes. However, the differences in the pattern and morphology of the B subunit-treated cells were distinct, and the B subunit clearly caused enhancement of neurite outgrowth (cf. Fig. $3 A, B$ ). The effect of the $\mathrm{B}$ subunit was greatly increased after pretreatment with NA (Fig. $3 D$ ). In contrast, NA treatment alone had no effect on the morphology or neuritogenesis (Fig. $3 \mathrm{C}$ ). These experiments were also carried out in cells grown in chemically defined serum-free medium to avoid complications due to the complex nature of serum and its multiplicity of actions. Upon removal of serum, cells rapidly differentiated and acquired morphological characteristics of neurons (cf. Figs. $3 A, 4 A$ ). Neuritogenesis was apparent after 12 $\mathrm{hr}$ of exposure, but the cells were not scored for neurite-bearing cells until $24 \mathrm{hr}$. After $24 \mathrm{hr}$ treatment with the B subunit, the percent of cells bearing neurites increased from $23.3 \pm 3 \%$ to $57 \pm 4.5 \%$. Cellular differentiation was marked by appearance of more numerous spinelike processes and a more branched neurite pattern. Cells with elongated neurites were also significantly increased (Fig. 4B). Again, treatment with NA alone had no effect on neuritogenesis. The effect of NA on B subunit-

Table 2. Effect of NA treatment on ganglioside composition in neuroblastoma N18 cells

\begin{tabular}{|c|c|c|c|c|}
\hline \multirow[b]{2}{*}{ Ganglioside } & \multicolumn{2}{|c|}{$\begin{array}{l}\text { Sialic acid } \\
\text { (nmol/mg protein) }\end{array}$} & \multicolumn{2}{|c|}{$\%$ of total gangliosides } \\
\hline & Control & NA & Control & NA \\
\hline GDla & 1.82 & 0.38 & 44 & 11 \\
\hline GMl & 0.56 & 1.96 & 13 & 59 \\
\hline GM2 & 1.03 & 0.77 & 25 & 23 \\
\hline GM3 & 0.72 & 0.20 & 17 & 6 \\
\hline Total & 4.13 & 3.3 & & \\
\hline
\end{tabular}

N18 cells were incubated in the presence or absence of $\mathrm{NA}(0.01 \mathrm{U} / \mathrm{ml})$ for $4 \mathrm{hr}$ and analyzed for gangliosides as described previously (Masco and Seifert, 1990). 

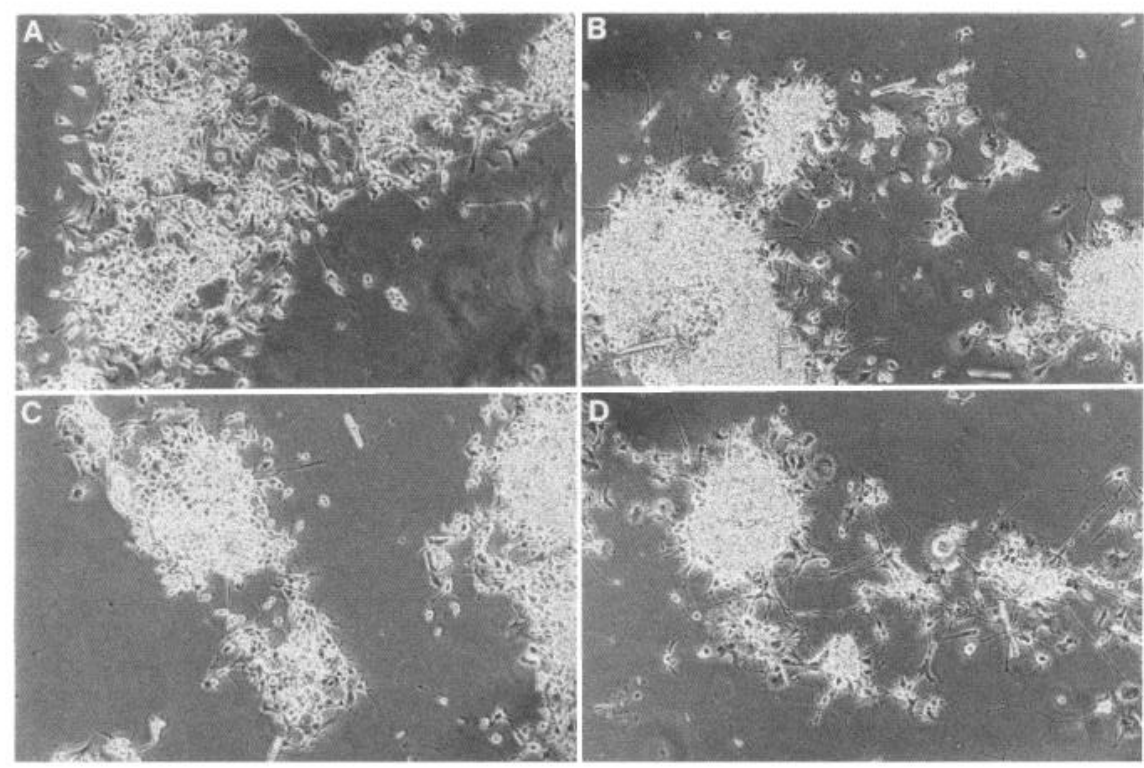

Figure 3. B subunit induces morphological differentiation of neuroblastoma N18 cells. Cells were grown in DMEM containing $5 \%$ FCS for $1 \mathrm{~d}$ and then incubated in the absence $(A)$ or in the presence $(B)$ of the B subunit $(4 \mu \mathrm{g} / \mathrm{ml})$. $C$, NA $(0.01 \mathrm{U} / \mathrm{ml})$ alone. $D$, NA together with the B subunit. Twenty-four hours after the various treatments, the cells were fixed, and photographs were taken at $100 \times$ magnification. induced differentiation in serum-free medium was only marginal. This is likely due to the large degree of differentiation induced by the B subunit alone. In all of these experiments, the results of the effects of the commercial and the cloned B subunit were indistinguishable. Surprisingly, the effect of the intact CT on neuritogenesis was similar to that induced by the B subunit despite the large increase in cAMP.

Additional evidence for the distinct morphological alteration and neuritogenesis in response to the B subunit was revealed by immunofluorescence with fluorescein-labeled B subunit (Fig. 5 ). The biological effect of the fluorescein-conjugated B subunit was comparable to the unmodified B subunit (data not shown). Similar to the unmodified B subunit, the fluorescein isothiocyanate conjugated (FITC)-B subunit also induced large increases in the percent of cells bearing neurites. Strong fluorescence in the thick neurite trunks and in the numerous and thin filaments around the cell body, the growth cone, and especially in spinelike processes was revealed in cells treated with FITClabeled B subunit for $24 \mathrm{hr}$ (Fig. 5B). Incubations for shorter periods of time did not cause detectable morphological alterations, which were only apparent after $12 \mathrm{hr}$.
Lack of effect of thrombin on neurite outgrowth induced by the B subunit

In view of the studies indicating that neurite outgrowth activity might be controlled by thrombin (or thrombin-like proteases; Gurwitz and Cunningham, 1988), we examined the effect of thrombin on neurite outgrowth produced by the B subunit. When cells were cultured for $2 \mathrm{~d}$ in the absence of serum, $15-20 \%$ of the cells showed neurites. The addition of $1 \mu \mathrm{g} / \mathrm{ml}$ of thrombin caused a fast neurite retraction within $3-4 \mathrm{hr}$ (Fig. $6 \mathrm{~A}, \mathrm{C}$ ). The ability of thrombin to block spontaneous differentiation was readily reversible. When thrombin was removed, neurite extension proceeded in serum-free medium at the same rate observed in cells not treated with thrombin. In sharp contrast to its effect on neurite extension induced in response to serum withdrawal, thrombin did not retract neurites extended in response to the $\mathrm{B}$ subunit (Fig. $6 C, D$ ). In addition, thrombin treatment did not block the inhibition of DNA synthesis induced by the B subunit (Table 4). It is interesting to note that thrombin alone has no effect on DNA synthesis, though it can completely reverse spontaneous neurite outgrowth when serum is removed.

Table 3. Effect of NA treatment on the B subunit-mediated inhibition of ${ }^{3} \mathrm{H}$-thymidine incorporation in neuroblastoma $\mathrm{N} 18$ cells

${ }^{3} \mathrm{H}$-thymidine incorporation

\begin{tabular}{|c|c|c|c|c|}
\hline \multirow{2}{*}{$\begin{array}{l}\text { Culture } \\
\text { condition }\end{array}$} & \multicolumn{4}{|c|}{$\begin{array}{l}{ }^{3} \mathrm{H} \text {-thymidine incorporation } \\
\left(\mathrm{cpm} \times 10^{-3}\right)\end{array}$} \\
\hline & Control & NA & B subunit & NA plus B subunit \\
\hline Medium I & $82.8 \pm 1$ & $82.9 \pm 2$ & $51.8 \pm 3$ & $21.0 \pm 1$ \\
\hline $0 \% \quad$ FCS & $16.1 \pm 1$ & $19.9 \pm 1$ & $11.8 \pm 1$ & $4.7 \pm 1$ \\
\hline $1 \%$ FCS & $77.6 \pm 5$ & $85.1 \pm 2$ & $64.5 \pm 2$ & $32.2 \pm 4$ \\
\hline $2.5 \%$ FCS & $92.5 \pm 1$ & $83.6 \pm 1$ & $79.6 \pm 2$ & $38.3 \pm 2$ \\
\hline $5 \% \quad$ FCS & $61.1 \pm 2$ & $51.4 \pm 2$ & $48.6 \pm 1$ & $28.1 \pm 1$ \\
\hline
\end{tabular}

Cells were grown for $3 \mathrm{~d}$ in the indicated medium and then incubated in the absence (control) or presence of NA ( 0.01 $\mathrm{U} / \mathrm{ml})$ or the B subunit $(4 \mu \mathrm{g} / \mathrm{ml})$ or NA $(0.01 \mathrm{U} / \mathrm{ml})$ plus the B subunit $(4 \mu \mathrm{g} / \mathrm{ml})$ for $20 \mathrm{hr}$. ${ }^{3} \mathrm{H}$-thymidine incorporation was measured as described in Materials and Methods. Each value is the mean \pm SD of triplicate determinations from a representative experiment. Similar results were obtained in at least five additional experiments. 
Figure 4. B subunit induces neurite outgrowth in neuroblastoma N18 cells grown in chemically defined medium. Cells were grown in chemically defined medium for $1 \mathrm{~d}$ as described in Materials and Methods and then incubated in the absence $(A)$ or in the presence $(B)$ of the B subunit $(4 \mu \mathrm{g} / \mathrm{ml})$. $C$, NA $(0.01$ $\mathrm{U} / \mathrm{ml}$ ) alone. $D$, NA together with the B subunit. Twenty-four hours after the various treatments, the cells were fixed, and photographs were taken at $200 \times$ magnification. The percentages of neurite-bearing cells were untreated control, $23.3 \pm 3 \%$; B subunit, $56.7 \pm 9 \%$; NA alone, $30.8 \pm 8 \%$; NA plus $\mathrm{B}$ subunit, $57.3 \pm 9 \%$.
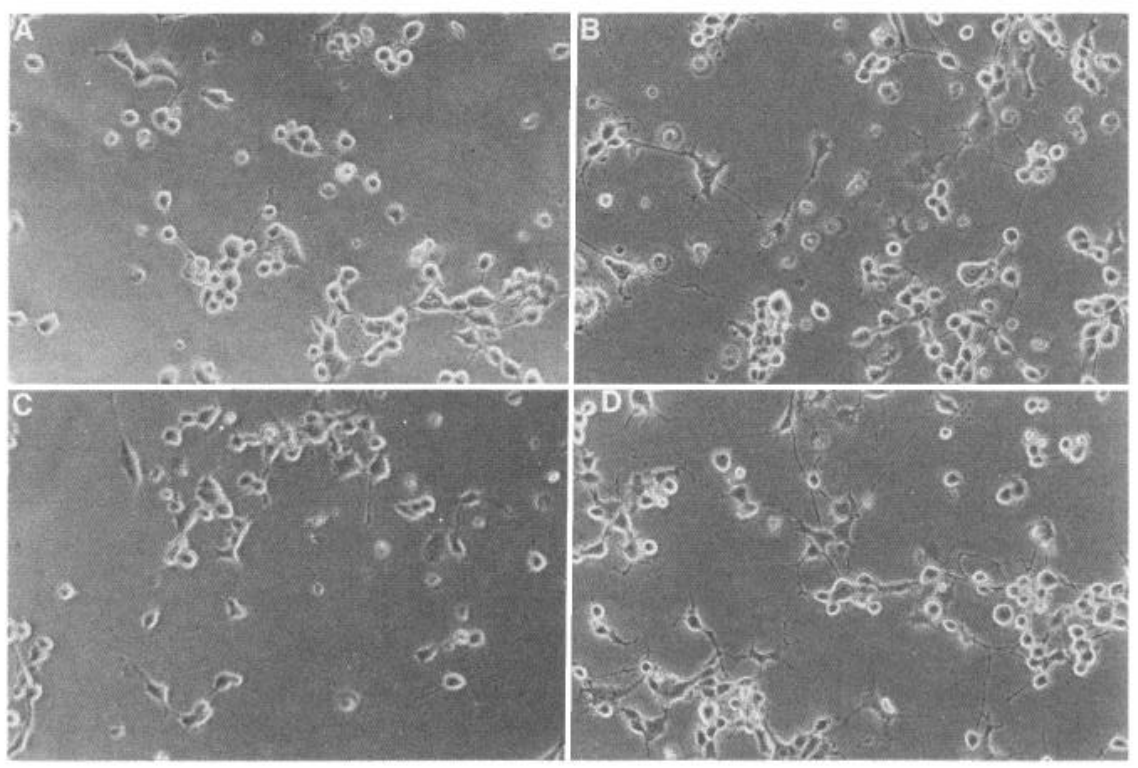

\section{Discussion}

Numerous reports have previously shown that both unfractionated gangliosides extracted from bovine brain and highly purified monosialoganglioside GM1 stimulate neuronal sprouting in vitro and in vivo (reviewed in Ledeen, 1989). However, the involvement of endogenous gangliosides in this process remains unclear. The observations that exogenous GM1 is stably inserted into neuronal and glial plasma membranes (Toffano et al.,
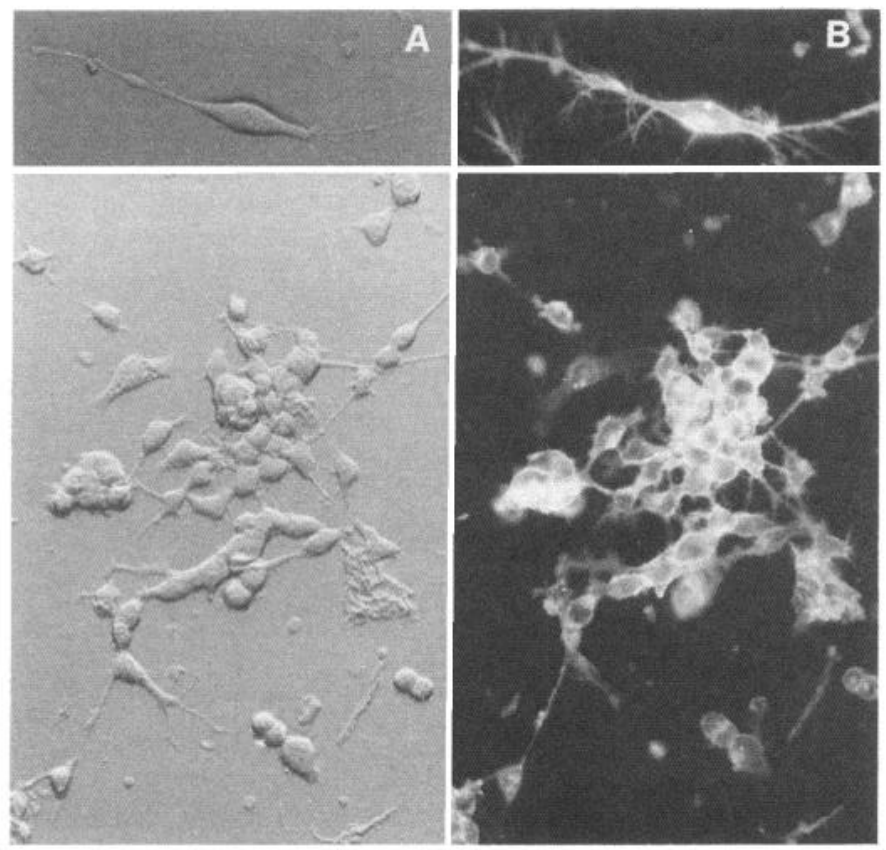

Figure 5. FITC-labeled B subunit distribution in neuroblastoma N18 cells. N18 cells grown in chemically defined medium on cover slides as described in Materials and Methods were exposed to FITC-B subunit for $24 \mathrm{hr}$ fixed, and then examined by phase-contrast $(A)$ and fluorescence microscopy $(B)$. Treatment of the cells with a large excess of unlabeled B subunit or with FITC-labeled B subunit preincubated with excess ganglioside GM1 completely inhibited the fluorescence. Magnifications, $400 \times$ (top) and $200 \times$ (bottom).
1980; Masco et al., 1989) and that following such insertion it can act as a functional receptor for CT (Fishman, 1982; Spiegel, 1988) lend support to the contention that in the nervous system the effects of exogenous ganglioside GM1 may reflect the function of its endogenous counterpart. The examination of the role of endogenous gangliosides in modulating neuritogenesis presents a more difficult task due to the lack of specific probes. One notable exception is the B subunit of CT, which displays an absolute affinity for ganglioside GM1 (Fishman, 1982).

The present study uses the B subunit to examine the role of ganglioside GM1 in the process of growth and differentiation of neuroblastoma $\mathrm{N} 18$ cells. Our data demonstrate that binding of the B subunit to $\mathrm{N} 18$ cells induces a significant decrease in DNA synthesis and pronounced morphological changes: an increase in neurite outgrowth concomitant with more branched neurites and the formation of more spinelike processes. The inhibition of proliferation of the $\mathrm{N} 18$ cells was more pronounced in serum-free medium. However, morphological changes were observed even at high serum concentrations. It should be noted that cells cultured in high serum content $(5-10 \%)$ grew as aggregates and had lower rates of proliferation and decreased ability to extend neurites. Although the underlying molecular mechanism involved in the process of neuritogenesis is not yet known, the results presented here suggest that the effects are due to the binding of the B subunit to ganglioside GM1 and not due to

Table 4. Lack of effect of thrombin on DNA synthesis induced by the B subunit in neuroblastoma N18 cells

\begin{tabular}{lll} 
& $\begin{array}{l}{ }^{3} \mathrm{H}-\text { thymidine incorporation } \\
\left(\mathrm{cpm} \times 10^{-3} \text { per well }\right)\end{array}$ & \\
\cline { 2 - 3 } Addition & Without B subunit & With B subunit \\
\hline None & $30.1 \pm 1$ & $20.6 \pm 0.81$ \\
Thrombin & $27.0 \pm 1.3$ & $18.8 \pm 0.8$
\end{tabular}

Neuroblastoma N18 cells were seeded in chemically defined medium (medium I) at a density of $2 \times 10^{3}$ cells per well in 96-well clusters. After $1 \mathrm{~d}$, the cells were exposed to the indicated reagents and ${ }^{3} \mathrm{H}$-thymidine incorporation was measured after $20 \mathrm{hr}$ as described in Materials and Methods. Each value is the mean \pm SD of triplicate determinations from a representative experiment. Similar results were obtained in at least five additional experiments. The concentrations of the agents were as follows: B subunit, $4 \mu \mathrm{g} / \mathrm{ml}$; thrombin, $1 \mu \mathrm{g} / \mathrm{ml}$. 

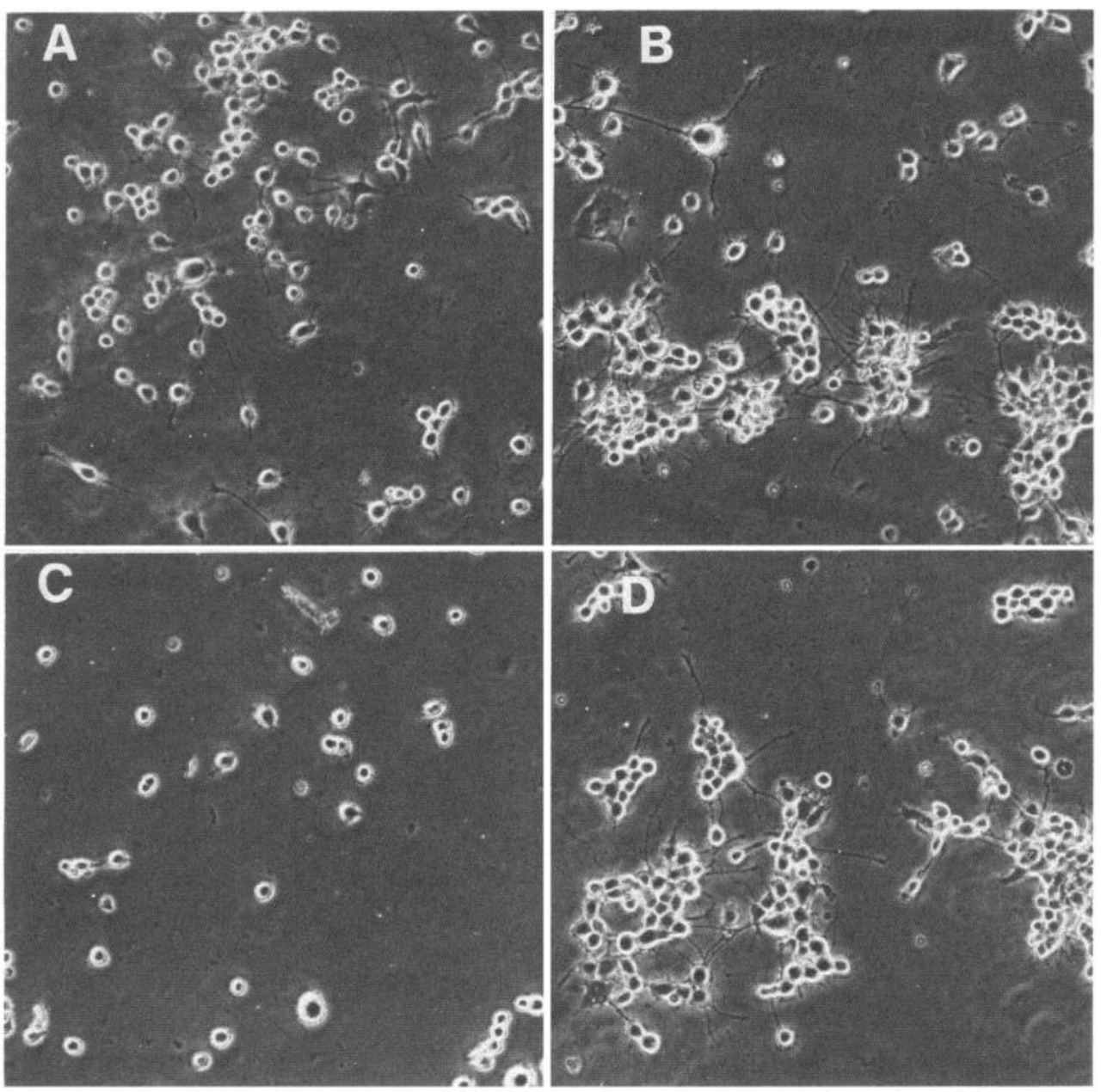

Figure 6. Lack of effect of thrombin on neurite outgrowth induced by the B subunit in neuroblastoma N18 cells. Cells were grown in chemically defined medium as described in Materials and Methods. After $20 \mathrm{hr}$ in the absence ( $A$, $C)$ or presence $(B, D)$ of B subunit (4 $\mu \mathrm{g} / \mathrm{ml})$, the cells were treated with thrombin $(1 \mu \mathrm{g} / \mathrm{ml})$ for $4 \mathrm{hr}(B, D)$ and fixed, and photographs were taken at $200 \times$ magnification. $A$, Untreated controls. $B$, B subunit. $C$, Thrombin. $D$, B subunit plus thrombin. Note the absence of neurite retraction in the B subunit-treated cells. changes in cAMP levels resulting from any contaminating A subunit. Several lines of evidence support this conclusion. First, we used highly purified cloned B subunit that cannot contain any $A$ subunit because it was isolated from a $V$. cholerae mutant that only expresses the B subunit. Second, neither the commercial preparation nor the cloned B subunit induced increases of cAMP in these cells, while under the same conditions, the holotoxin (A and B subunits) caused dramatic increases in cAMP levels. Third, there was a good correlation between the amount of B subunit bound to the cells and the biological effect. Finally, treatment with NA, which caused a fourfold increase in the level of membrane GM1 as determined by iodinated-CT binding, enhanced the biological effect of the B subunit.

However, experiments with NA are subject to some drawbacks. NA not only removes the sialic acid residues of polysialogangliosides, converting them to GM1, it also removes sialic acid from other gangliosides belonging to other series (neolacto, globo), leading to increases in various other glycosphingolipids, and will hydrolyze terminal sialic acids from glycoproteins. The fact that NA treatment alone did not have significant effects, either on DNA synthesis or on morphology of the cells, indicates that elevations in the level of GM1 per se are not sufficient by themselves to cause significant changes in cell growth or differentiation and that it is either the aggregation of GM1 on the cell surface by the B subunit or the displacement of endogenous ligands from GM1 that is responsible for the effect. During the course of this work, Wu and Ledeen (1991) reported that treatment of mouse neuroblastoma N2A and rat neuroblastomas B50 and B104 with NA induced enhanced neurite outgrowth, while N1A-103 mouse neuroblastoma was unresponsive to NA. Furthermore, NA-stimulated neuritogenesis was blocked by the B subunit. These results are not readily reconcilable with the results presented here. However, the possibility that different cell types respond differently to the B subunit cannot be ruled out. In this regard, a dual action of the B subunit was recently observed in different cell types. For example, the growth of resting thymocytes and $3 \mathrm{~T} 3$ fibroblasts was stimulated by the B subunit, while the growth of transformed cells, such as rastransformed 3T3 fibroblasts and C6 cells, was inhibited (Spiegel et al., 1985b; Spiegel and Fishman, 1987; Facci et al., 1988; Skaper et al., 1988; Spiegel, 1988). Furthermore, experiments with growing 3T3 fibroblasts revealed that a bimodal response to the B subunit can be observed in the same cell line, depending on their growth state (Spiegel and Fishman, 1987). The biphasic response to the B subunit by the same $3 \mathrm{~T} 3$ fibroblasts raised the possibility that endogenous ganglioside GM1 could function as a bimodal regulator of cell growth signals. Based on the observation that the levels of cell-surface GM1 were reduced in the growing ras-transfected cells and increased as the untransfected NIH 3T3 cells became contact inhibited (Matyas et al., 1987), it has been proposed that the ability of ganglioside GM1 to regulate positive and negative signals may depend on its 
density on the cell surface. However, further studies revealed that this is an oversimplification. Using the unique ability of gangliosides to be functionally inserted into the plasma membrane of cells, it was found that, even after the levels of GM 1 on the surface of rapidly dividing cells were increased to levels found on confluent cells, the responsiveness to the B subunit was not altered. Furthermore, similar results were obtained when the level of endogenous GM1 was increased by treatment of the cells with NA to convert polysialogangliosides to GM1. Therefore, these experiments indicate that the bimodal response to the $B$ subunit is not solely a function of the concentration of cell-surface GM1; rather, it is the growth stage that determines the fate of the signal transduced by the interaction of the B subunit and ganglioside GM1 (Buckley et al., 1990). In agreement with this hypothesis, it was recently observed that the B subunit has a dual action in quiescent Swiss 3T3 fibroblasts, depending on the context of other growth factors (Spiegel, 1989). While the B subunit potentiated the effect of epidermal growth factor, insulin, bombesin, and platelet-derived growth factor, it diminished the stimulation of DNA synthesis induced by phorbol esters via protein kinase $C$. Similar results were obtained in quiescent rat thyroid FRTL- 5 cells, where a biphasic response was also observed (Tetsumoto et al., 1988).

It is clcar that the cessation of growth is usually a necessary condition for the onset of differentiation in most cells. The B subunit inhibits DNA synthesis of neuroblastoma N18 cells and induces enhanced neuritogenesis, an indicator of differentiation. Similar to the observations presented here, it has recently been shown that in astroglial cells the B subunit inhibited DNA synthesis concomitant with the induction of a classical star-shaped (stellate) morphology, a process associated with a more differentiated state (Facci et al., 1988). It is possible that the B subunit exerts its effect by binding to endogenous ganglioside GM1, thereby displacing or preventing the binding of a factor that normally stimulates growth. Support for this hypothesis comes from a recent study of the effect of exogenous GM1 on the growth of S20Y murine neuroblastoma. The oligosaccharide portion alone of GMI enhanced neuritogenesis of these cells to the same extent as intact GM1 (Schengrund and Prouty, 1988). Because it is most unlikcly that the oligosaccharide portion penetrates the plasma membrane, it has been suggested that S20Y neuroblastoma cells have cell-surface ganglioside binding sites that are crucial for cell growth regulation and that recognize the oligosaccharide moiety of GMl (Schengrund and Prouty, 1988). Evidence is also accumulating for the existence of cell-surface ganglioside binding proteins (Blackburn et al., 1986; Tiemeyer et al., 1989).

From another point of view, the B subunit might mimic the effect of an unknown neuronotrophic factor that binds to GM1. In this respect, it was demonstrated that conditioned media derived from several cell types produced neuritogenesis in chick dorsal root ganglia in culture and that monoclonal antibodies to GM1 blocked this effect (Spoerri et al., 1988). These results suggest the presence in the conditioned media of a substance capable of binding to GMI and inducing neurite outgrowth. It is tempting to speculate that this cndogenous ncuritogenesis factor could be similar to the B subunit. The mechanism of $B$ subunit-induced differentiation is different than that of spontaneous differentiation. It has been shown that thrombin, a serine protease present in normal serum, inhibits neurite outgrowth induced by the removal of serum from the media (Gurwitz and Cunningham, 1988). In contrast, thrombin did not cause re- traction of the neurites induced by the B subunit. Therefore, there is no indication of a possible involvement of thrombin or a thrombin-like protease in the control of neurite outgrowth mediated through GM1.

Although the underlying mechanism of the B subunit effect remains elusive, cross-linking of GMl by the B subunit may modulate ion channels in the plasma membrane. Recently, we found that the B subunit can modulate calcium permeability in thymocytes as well as in fibroblasts (Dixon et al., 1987; Spiegel and Panagiotopoulos, 1988). The B subunit may have similar effects on neuroblastoma cells. Many studies have implicated calcium ion in the regulation of neurite outgrowth in both vertebrates and invertebrates, and in neurons in culture (Reboulleau, 1986; Kater et al., 1988). Ganglioside GM1 might have an important role in regulating calcium fluxes and thus regulate neurite elongation. This hypothesis is currently under investigation.

The results presented here suggest that endogenous ganglioside GM 1 may play a role in the differentiation and proliferation of neural cells. Based on its neural regenerative effects, ganglioside GMI has been used successfully in animal models of certain neurological disorders, such as for diabetic neuropathy (Calcutt et al., 1988) and for acceleration of functional recovery after CNS damage (Karpiak et al., 1987). The use of ganglioside GM 1 has recently been extended to human treatment. Our findings suggest that these therapeutic effects of ganglioside GM1 might be a reflection of their normal function in neuronal cells. Further studies addressing the underlying molecular mechanisms of the role of gangliosides in neural growth and differentiation are presently under investigation.

\section{References}

Blackburn CC, Swank-Hill P, Schnaar RL (1986) Gangliosides support neural retina cell adhesion. J Biol Chem 261:2873-2881.

Buckley N, Matyas G, Spiegel S (1990) The bimodal growth response of Swiss 3T3 cells to the B subunit of cholera toxin is independent of the density of its receptor, ganglioside GM1. Exp Cell Res 189:1321

Byrne MC, Ledeen RW, Roisen FJ, Yorke G, Sclafani JR (1983) Ganglioside-induced neuritogenesis: verification that gangliosides are the active agents, and comparison of molecular species. J Neurochem 41 : 1214-1222.

Calcutt N, Tomlinson D, Willars G (1988) Gangliosides treatment of streptozotocin-diabetic rats prevents defective axonal transport of 6-phosphofructokinase activity. J Neurochem 50:1478-1483.

Cannella M, Wu G, Vaswani K, Ledeen R (1988) Neuritogenic effects of exogenous gangliosides and synthetic sialoglycolipids: comparison to endogenous ganglioside requirements. In: New trends in ganglioside research: neurochemical and neurogenerative aspects (Ledeen $\mathrm{R}, \mathrm{Ho}-$ gan E, Tettamanti G, Yates A, Yu R, eds), pp 379-390. Padova: Liviana.

Dekker A, Manthorpe M, Varon S (1990) Reversibility of ganglioside effects on astrocyte morphology. J Neurosci Res 26:349-355.

Dimpfel W, Moller W, Mengs U (1981) Ganglioside induced neurite formation in cultured neuroblastoma cells. In: Gangliosides in neurological and neuromuscular function, development, and repair (Rapport MM, Gorio A, eds), pp 119-134. New York: Raven.

Dixon SJ, Stewart D, Grinstein S, Spiegel S (1987) Transmembrane signaling by the B subunit of cholera toxin: increased cytoplasmic free calcium in rat lymphocytes. J Cell Biol 105:1153-1161.

Doherty P, Walsh FS (1987) Ganglioside GM1 antibodies and B-cholera toxin bind specifically to embryonic chick dorsal root ganglion neurons but do not modulate neurite regeneration. $J$ Neurochem 4 : $1237-1244$

Dreyfus H, Ferret B, Harth S, Gorio A, Freysz L, Massarelli R (1984) Effect of exogenous gangliosides on the morphology and biochemistry of cultured neurons. In: Ganglioside structure, function, and bio- 
medical potential (Ledeen RW, Yu RK, Rapport MM, Suzuki K, eds), pp 513-524. New York: Plenum.

Duffard RO, Fishman PH, Bradley RM, Lauter CJ, Brady RO, Trams EG (1977) Gangliosidc composition and biosynthesis in cultured cells derived from CNS. J Neurochem 28:1161-1166.

Facci L, Leon A, Toffano G, Sonnino S, Ghidoni R, Tettamanti G (1984) Promotion of neuritogenesis in mouse neuroblastoma cells by exogenous gangliosides. Relationship between the effect and the cell association of ganglioside GM1. J Neurochem 42:299-305.

Facci L, Skaper S, Favaron M, Leon A (1988) A role for gangliosides in astroglial cell differentiation in vitro. J Cell Biol 106:821-828.

Ferrari G, Fabris M, Gorio A (1983) Gangliosides enhance neurite outgrowth in PC12 cells. Dev Brain Res 8:215-222.

Fishman PH (1980) Mechanisms of the action of cholera toxin: studies of the lag period. J Membr Biol 54:61-72.

Fishman PH (1982) Role of membrane gangliosides in the binding and action of bacterial toxins. J Membr Biol 69:85-97.

Gilman AG (1984) Proteins and dual control of adenylate cyclase. Cell 36:577-579.

Gurwitz D, Cunningham DD (1988) Thrombin modulates and reverses neuroblastoma neurite outgrowth. Proc Natl Acad Sci USA $85: 3440-3444$.

Hakomori S (1981) Glycosphingolipids in cellular interaction, differentiation and oncogenesis. Annu Rev Biochem 50:733-764.

Hauw JJ, Fenelon S, Boutry JM, Nagai Y, Escourolle R (1981) Effects of brain gangliosides on neurite outgrowth in guinea pig spinal ganglia tissue culture and on fibroblast cell culture. In: Gangliosides in neurological and neuromuscular function, development, and repair (Rapport MM, Gorio A, eds), pp 171-176. New York: Raven.

Karpiak SE, Li YS, Mahadik SP (1987) Ganglioside treatment: reduction of CNS injury and facilitation of functional recovery. Brain Injury $1: 141-170$.

Kater S, Mattson M, Cohan C, Connor J (1988) Calcium regulation of the neuronal growth cone. Trends Neurosci 11:315-321.

Katoh-Semba R, Skaper SD, Varon S (1984) Interaction of GM1 ganglioside with $\mathrm{PC} 12$ pheochromocytoma cells: serum and NGFdependent effects on neurite growth and proliferation. J Neurosci Res 12:299-310.

Ledeen RW (1985) Gangliosides of the neuron. Trends Neurosci 8: 169-174.

Ledeen RW (1989) Biosynthesis, metabolism and biological effects of gangliosides. In: Neurobiology of glycoconjugates (Margolis RU, Margolis RK, eds), pp 43-83. New York: Plenum.

Leon A, Facci L, Benvegnu D, Toffano G (1982) Morphological and biochemical effects of gangliosides in neuroblastoma cells. Dev Neurosci 5:108-114.

Liu Y, Fiske W, Chen Y (1980) Regulation of cyclic adenosine 3':5'monophosphate-binding protein in N-18 mouse neuroblastoma cells. Cancer Res 40:4100-4108.

Lowry OH, Rosenbrough NJ, Farr AL, Randall RJ (1951) Protein measurement with the Folin phenol reagent. J Biol Chem 193:265275.

Mahadik SP, Laev H, Rapport MM (1986) Preparation and specificity of 11 monoclonal antibodies to GM1 ganglioside. J Neurochem 47: $1172-1175$.

Masco D, Seifert W (1990) Gangliosides in lesion-induced synaptogenesis: studies in the hippocampus of the rat brain. Brain Res 514: 84-92.

Masco D, Flott B, Seifert W (1989) Astrocytes in cell culture incorporate GM1 gangliosidc. Glia 2:231-240.

Matta SG, Yorke G, Roisen F (1986) Neuritogenic and metabolic effects of individual gangliosides and their interaction with nerve growth factor in cultures of neuroblastoma and pheochromocytoma. Dev Brain Res 27:242-252.

Matyas G, Aaronson S, Brady R, Fishman PH (1987) Alteration of glycolipids in ras-transfected NIH 3T3 cells. Proc Natl Acad Sci USA 84:6065-6068

Miller-Podraza H, Fishman PH (1982) Translocation of newly synthesized gangliosides to the cell surface. Biochemistry 21:3265-3270.

Miller-Podraza H, Bradley R, Fishman PH (1982) Biosynthesis and localization of gangliosides in cultured cells. Biochemistry 21:32603265 .

Morgan J, Seifert W (1979) Growth factors and gangliosides: a possible new perspective in neuronal growth control. J Supramol Struct 10: 111-124.
Prasad K, Hsie A (1971) Morphological differentiation of mouse neuroblastoma cells induced in vitro by dibutyryl adenosine $3^{\prime}: 5^{\prime}$ cyclic monophosphate. Nature (New Biol) 233:141-142.

Reboulleau CP (1986) Extracellular calcium-induced neuroblastoma cell differentiation: involvement of phosphatidylinositol turnover. $\mathrm{J}$ Neurochem 46:920-930.

Richter-Landsberg C, Jastorff B (1986) The role of cAMP in nerve growth factor-promoted neurite outgrowth in PC12 cells. J Cell Biol 102:821-829.

Roisen FJ, Bartfeld H, Nagele R, Yorke G (1981) Ganglioside stimulation of axonal sprouting in vitro. Science 214:577-578.

Rybak S, Ginzburg I, Yavin E (1983) Gangliosides stimulate neurite outgrowth and induce tubulin mRNA accumulation in neural cells. Biochem Biophys Res Commun 116:974-980.

Schengrund CL, Prouty CP (1988) The oligosaccharide portion of GM1 enhances process formation by S20Y neuroblastoma cells. J Neurochem 51:277-282.

Schwartz M, Spirman N (1982) Sprouting from chicken embryo dorsal root ganglia induced by nerve growth factor is specifically inhibited by affinity-purified antiganglioside antibodies. Proc Natl Acad Sci USA 79:6080-6083.

Skaper S, Facci L, Favaron M, Leon A (1988) Inhibition of DNA synthesis in C6 glioma cells following cellular incorporation of GM 1 ganglioside and choleragenoid exposure. J Neurochem 51:688-697.

Spiegel S (1988) Insertion of ganglioside GM1 into rat glioma C6 cells renders them susceptible to growth inhibition by the B subunit of cholera toxin. Biochim Biophys Acta 969:249-256.

Spiegel S (1989) Inhibition of protein kinase C-dependent cellular proliferation by interaction of endogenous ganglioside GM1 with the B subunit of the cholera toxin. J Biol Chem 264:16512-1657.

Spiegel S, Fishman PH (1987) Gangliosides as bimodal regulators of cell growth. Proc Natl Acad Sci USA 84:141-147.

Spiegel S, Panagiotopoulos C (1988) Mitogenesis of 3T3 fibroblasts induced by endogenous gangliosides is not mediated by cAMP, protein kinase C, or phosphoinositides turnover. Exp Cell Res 177:414427.

Spiegel S, Yamada KM, Hom BE, Moss J, Fishman PH (1985a) Fluorescent gangliosides as probes for the retention and organization of fibronectin by ganglioside-deficient mouse cells. J Cell Biol 100:721726.

Spiegel S, Fishman PH, Weber RJ (1985b) Direct evidence that endogenous GM 1 ganglioside can mediate thymocyte proliferation. Science 230:1285-1287.

Spirman N, Sela B, Schwartz M (1982) Antiganglioside antibodies inhibit neuritic outgrowth from regenerating goldfish retinal explants. J Neurochem 39:874-877.

Spoerri P, Rapport M, Mahadik S, Roisen F (1988) Inhibition of conditioned media-mediated neuritogenesis of sensory ganglia by monoclonal antibodies to GM 1 ganglioside. Brain Res 469:71-77.

Spoerri PE (1983) Effects of gangliosides on the in vitro development of neuroblastoma cells: an ultrastructural study. Int J Dev Neurosci 1:383-391.

Svennerholm L (1963) Chromatographic separation of human brain gangliosides. J Neurochem 10:613-623.

Sweeley CC, Siddiqui B (1977) Chemistry of mammalian glycolipids. In: The Glycoconjugates, Vol 1 (Pigman W, Horowitz MI, eds), pp 459-540. New York: Academic.

Taylor RK, Miller VL, Furlong DB, Mekanos JJ (1987) Use of PhoA gene fusion to identify a pilus colonization factor coordinately regulated with cholera toxin. Proc Natl Acad Sci USA 84:2833-2837.

Tetsumoto T, Takada K, Amino N, Miyai K (1988) Regulation of proliferation by the cholera toxin B subunit in FRTL-5 cells may involve a mechanism independent from the modulation of membrane receptor function. Biochem Biophys Res Commun 157:605-610.

Tiemeyer M, Yasuda Y, Schnaar R (1989) Ganglioside-specific binding protein on rat brain membranes. J Biol Chem 264:1671-1681.

Toffano G, Benvengnu D, Bonetti A, Facci L, Leon A, Orlando P, Ghidoni R, Tettamanti G (1980) Interaction of GM1 ganglioside with crude rat brain neuronal membranes. J Neurochem 35:861-866.

Tsuji S, Arita M, Nagai Y (1983) GQlb, a bioactive ganglioside that exhibits novel nerve growth factor (NGF)-like activities in the two neuroblastoma cell lines. J Biochem (Tokyo) 94:303-306.

Van de Walle M, Fass R, Shiloach J (1990) Production of cholera toxin subunit B by a mutant strain of Vibrio cholera. Appl Microbiol Biotechnol 33:389-394. 
Wu G, Ledeen R (1991) Stimulation of neurite outgrowth in neuroblastoma cells by neuraminidase: putative role of GM1 ganglioside in calcium-mediated differentiation. J Neurochem 56:95-104.
Yates AJ (1986) Gangliosides in the nervous system during development and regeneration. Neurochem Pathol 5:309-329. 